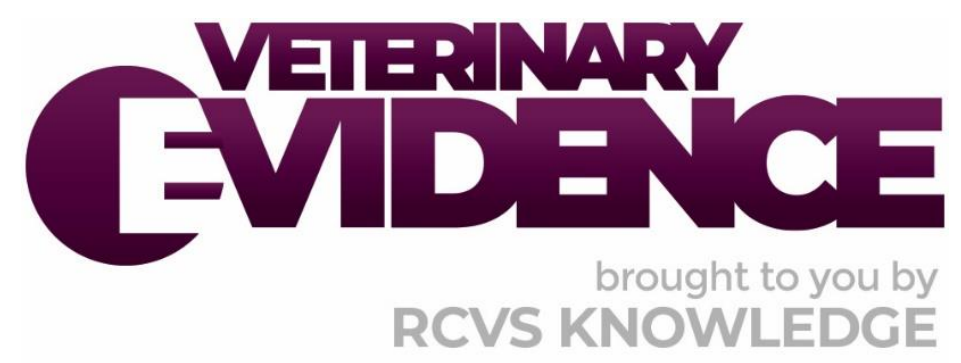

\title{
Uncomplicated gallbladder mucoceles - is it better for prognosis to perform cholecystectomy or medically manage?
}

\author{
A Knowledge Summary by
}

Rachel T. Griffiths DVM BS ${ }^{*}$

Wanda J. Gordon-Evans DVM PhD DACVS DACVSMR ${ }^{1}$

\footnotetext{
1 University of Minnesota College of Veterinary Medicine, Gortner Ave, St. Paul, MN 55108

* Corresponding Author (grif0325@umn.edu)
}

ISSN: 2396-9776

Published: 10 Jun 2021

in: The Veterinary Evidence journal Vol 6, Issue 2

DOI: https://doi.org/10.18849/ve.v6i2.395

Reviewed by: Fergus Allerton (BSc BVSc CertSAM DipECVIMCA MRCVS) and Adam Swallow (BVSc MRCVS) 


\section{KNOWLEDGE SUMMARY}

\section{PICO question}

In dogs with an uncomplicated gallbladder mucocele, is the long-term survival when surgically managed superior, inferior, or equal to those medically managed?

\section{Clinical bottom line}

\section{Category of research question}

Treatment and prognosis

\section{The number and type of study designs reviewed}

Three papers were critically reviewed. All of the studies were retrospective analyses of medical records, two of which were cohort studies, and one which was a case control study

\section{Strength of evidence}

Weak

\section{Outcomes reported}

There is some evidence that surgical management of gallbladder mucoceles is associated with longer survival times than medically managed cases, although there is no direct analysis of uncomplicated vs complicated cases

\section{Conclusion}

We cannot clearly make a conclusion based on the available evidence. To date, there is only one retrospective analysis that directly compares the long-term survival of cases medically vs surgically managed, but this study does not separate uncomplicated vs complicated cases of gallbladder mucocele. In order to more accurately determine which type of treatment should be recommended for uncomplicated cases of gallbladder mucoceles, a prospective study comparing long-term survival with each treatment should be performed. These studies should also standardise medical management in order to more accurately compare survival time to surgical treatment

\section{How to apply this evidence in practice}

The application of evidence into practice should take into account multiple factors, not limited to: individual clinical expertise, patient's circumstances and owners' values, country, location or clinic where you work, the individual case in front of you, the availability of therapies and resources.

Knowledge Summaries are a resource to help reinforce or inform decision making. They do not override the responsibility or judgement of the practitioner to do what is best for the animal in their care. 


\section{Clinical Scenario}

You are presented with a dog that underwent a routine abdominal ultrasound, which showed an incidental finding of a gallbladder mucocele that has no signs of visual rupture and is without a significant cholestatic pattern in a routine chemistry. You would like to know if the patient will have a better prognosis if you recommend cholecystectomy now or if you medically manage the patient instead of performing surgery. Based on any differences in prognosis, this will help you recommend treatments to the patient's owner.

\section{The evidence}

The evidence consists of retrospective analyses of medical records from various veterinary hospitals, primarily cohort studies with one case control study performed in the UK. Retrospective studies have inherent biases, and therefore provide weaker evidence than prospective analyses. To date, only one study directly compares long-term survival between surgically and medically managed cases (Parkanzky et al. 2018). Other studies included in this Knowledge Summary did not primarily aim to determine mean survival time between the two treatment types, but did provide some survival data. None of these studies directly compared medical and surgical treatment in uncomplicated cases of gallbladder mucoceles, and instead included both uncomplicated and complicated cases. As a result, it is difficult to establish a meaningful clinical difference in mean survival time between medically and surgically managed cases of uncomplicated gallbladder mucoceles in dogs. In order to better answer this question, more prospective analyses of medically and surgically managed cases of uncomplicated gallbladder mucoceles should be performed.

Abbreviations:

GBM - gallbladder mucocele

MST - mean survival time

\section{Summary of the evidence}

\begin{tabular}{|c|c|}
\hline \multicolumn{2}{|l|}{ Allerton et al. (2018) } \\
\hline Population: & $\begin{array}{l}\text { Dogs with ultrasonographic diagnosis of GBM from three referral } \\
\text { centres in the United Kingdom }\end{array}$ \\
\hline Sample size: & 186 dogs \\
\hline Intervention details: & $\begin{array}{l}\text { - } 99 \text { dogs with GBM, of which } 51 \text { were Border Terriers and } 48 \\
\text { were of various other breeds: } \\
0 \quad 77 / 99 \text { were surgically managed } \\
0 \quad 12 / 99 \text { were medically managed } \\
0 \quad 10 / 99 \text { were euthanised prior to receiving treatment } \\
\text { - } 87 \text { Border Terriers with no ultrasonographic evidence of } \\
\text { gallbladder disease were controls } \\
\text { - Patient data collected included breed, age, sex, neuter } \\
\text { status, bodyweight, presence or absence of previously } \\
\text { diagnosed endocrinopathies, results of complete blood } \\
\text { count (CBC) and serum biochemistry tests, and total } \\
\text { thyroxine levels } \\
\text { - Additional data was collected from the GBM cases - absence } \\
\text { of specific clinical signs, approach to case management } \\
\text { (surgical or medical), medications prescribed, presence or } \\
\text { absence of gallbladder rupture, outcome (survival } 7 \text { days, } 6 \\
\text { months, and } 1 \text { year post diagnosis; total survival time), and } \\
\text { cause of death }\end{array}$ \\
\hline
\end{tabular}




\begin{tabular}{|c|c|}
\hline Study design: & Retrospective case control \\
\hline Outcome studied: & $\begin{array}{l}\text { - The primary objective of this study was to establish if there } \\
\text { is a breed disposition to GBM development in Border } \\
\text { Terriers } \\
\text { - Identify potential breed-specific characteristics relating to } \\
\text { risk factors, clinical features, and outcome for the Border } \\
\text { Terriers by comparison to the control Border Terrier group } \\
\text { Determining possible causes of GBM in Border Terriers, } \\
\text { specifically finding the incidence of endocrinopathies and } \\
\text { clinicopathologic abnormalities in Border Terriers with GBM } \\
\text { (as compared to the control group) }\end{array}$ \\
\hline $\begin{array}{l}\text { Main findings: } \\
\text { (relevant to PICO question): }\end{array}$ & $\begin{array}{l}\text { - } 9 / 10(90 \%) \text { of medically managed cases survived greater } \\
\text { than } 1 \text { year } \\
\text { - } 39 / 49(80 \%) \text { of the surgically managed GBM cases survived } \\
\text { greater than } 1 \text { year } \\
\text { - } 26 / 34(76 \%) \text { of the Border Terriers survived greater than } 1 \\
\text { year and there was no statistically significant difference in } \\
\text { survival time according to breed status } \\
\text { - There was not a statistically significant difference in } 7 \text { days, } \\
6 \text { months, or } 1 \text { year survival between medically managed } \\
\text { and surgically managed groups } \\
\text { - MST could not be calculated for any group (<50\% case } \\
\text { fatality rate) }\end{array}$ \\
\hline Limitations: & $\begin{array}{l}\text { - This is a retrospective study, and therefore has more bias } \\
\text { than a prospective study } \\
\text { - This study focused on a single breed, and thus may not be } \\
\text { applicable to the canine species as a whole } \\
\text { - It is unclear how many dogs from the medically and } \\
\text { surgically managed groups had uncomplicated cases of GBM } \\
\text { vs complicated cases of GBM } \\
\text { - While the researchers did provide some survival data for the } \\
\text { GBM cases, over } 50 \% \text { of the population were still alive at the } \\
\text { time of census thus they could not calculate an MST }\end{array}$ \\
\hline
\end{tabular}

Parkanzky et al. (2019)

\begin{tabular}{|r|l|}
\hline Population: & $\begin{array}{l}\text { Dogs diagnosed with GBM that received either cholecystectomy, } \\
\text { medical treatment, or both. } \\
\text { Medical records were reviewed to select cases of dogs diagnosed } \\
\text { with GBM at University of Georgia College of Veterinary Medicine } \\
\text { between 2011-2017 }\end{array}$ \\
\hline Sample size: & 89 dogs \\
\hline Intervention details: & $\begin{array}{l}\text { Dogs were grouped based on whether they received surgical } \\
\text { treatment (46/89), medical treatment (33/89), or medical } \\
\text { treatment followed by surgery (10/89) }\end{array}$ \\
& $\begin{array}{l}\text { Data collected from each patient included signalment, } \\
\text { medical vs surgical interventions, CBC and serum } \\
\text { biochemistry data, ultrasonographic images of the } \\
\text { gallbladder, and survival status or date of death if applicable }\end{array}$ \\
\hline
\end{tabular}




\begin{tabular}{|c|c|}
\hline Study design: & Retrospective cohort study \\
\hline Outcome studied: & $\begin{array}{l}\text { Long-term prognostic outcome (survival analysis); identification of } \\
\text { clinical, clinicopathologic, and diagnostic imaging variable associated } \\
\text { with prognosis }\end{array}$ \\
\hline $\begin{array}{l}\text { Main findings: } \\
\text { (relevant to PICO question): }\end{array}$ & $\begin{array}{l}\text { - Of } 79 / 89 \text { ( } 89 \% \text { ) dogs surviving at least } 14 \text { days, MST of the } \\
\text { medically treated group ( } 1340 \text { days, } 95 \% \mathrm{CI} \text {, range } 444-1340 \\
\text { days) was significantly shorter than the surgically treated } \\
\text { group ( } 1802 \text { days, } 95 \% \mathrm{Cl} \text {, range } 855 \text { days-not reached) } \\
\text { MST of dogs treated with both medical and surgical } \\
\text { interventions ( } 203 \text { days, } 95 \% \mathrm{Cl} \text {, range } 18-525 \text { days) was } \\
\text { significantly shorter than the medical and surgical } \\
\text { intervention groups } \\
\text { - Patients lost to follow-up in the first } 14 \text { days after diagnosis } \\
\text { varied between intervention groups; } 12 / 46 \text { ( } 26.1 \% \text { ) of the } \\
\text { surgically managed cases, } 6 / 33(18.2 \%) \text { of the medically } \\
\text { managed cases, and } 0 / 10(0 \%) \text { of the combined medically } \\
\text { and surgically managed cases }\end{array}$ \\
\hline Limitations: & $\begin{array}{l}\text { - This is a retrospective study, and therefore has more bias } \\
\text { than a prospective study. Specifically, diagnostic approach, } \\
\text { recommended treatments, and case follow-up varied } \\
\text { between case and attending clinician } \\
\text { - Many cases were censored by researchers due to lack of } \\
\text { follow-up data - more in the medically managed group than } \\
\text { the surgically managed group } \\
\text { - Survival analysis also excluded patients that died before } 14 \\
\text { days, and it is unclear which of these patients were } \\
\text { uncomplicated vs. complicated cases of GBM (second } \\
\text { Kaplan-Meier analysis was included to remove death in the } \\
\text { postoperative period) } \\
\text { - Does not discuss or separate cases of uncomplicated GBM } \\
\text { from complicated cases (gallbladder rupture, peritonitis, } \\
\text { extrahepatic biliary tract rupture) } \\
\text { - Unable to determine if the group that was both medically } \\
\text { and surgically managed received surgical treatment because } \\
\text { they were complicated cases vs uncomplicated } \\
\text { - Medical management was not standardised } \\
\text { - Unequal treatment group sizes } \\
\text { Groups varied significantly in sex and in spay/neuter status }\end{array}$ \\
\hline
\end{tabular}

Pike et al. (2004)

\begin{tabular}{|r|c|}
\hline Population: & $\begin{array}{l}\text { Dogs diagnosed with GBM at Tufts University School of Veterinary } \\
\text { Medicine between January } 2000 \text { and December } 2002\end{array}$ \\
\hline Sample size: & $\begin{array}{l}30 \text { dogs with sonographic findings characteristic of GBM, and dogs } \\
\text { that underwent cholecystectomy }\end{array}$ \\
\hline Intervention details: & $\begin{array}{l}\text { A single intervention group of 23/30 (77\%) dogs that } \\
\text { underwent cholesystectomy were evaluated for long-term } \\
\text { survival }\end{array}$ \\
\hline
\end{tabular}




\begin{tabular}{|c|c|}
\hline & $\begin{array}{l}\text { - } 7 / 30(23 \%) \text { dogs were medically managed and were not } \\
\text { included in statistical analyses } \\
\text { Data collected from each patient included signalment, } \\
\text { nature and duration of clinical signs, physical examination } \\
\text { findings, results of clinicopathologic tests, ultrasonographic } \\
\text { reports, surgery reports, anesthesia records, and follow-up } \\
\text { owner reports of surgical success }\end{array}$ \\
\hline Study design: & Retrospective cohort study \\
\hline Outcome studied: & $\begin{array}{l}\text { - Long-term response to cholecystectomy } \\
\text { - Determine the clinical, clinicopathologic, ultrasonographic, } \\
\text { microbiologic, and histologic findings in dogs with GBM }\end{array}$ \\
\hline $\begin{array}{l}\text { Main findings: } \\
\text { (relevant to PICO question): }\end{array}$ & $\begin{array}{l}\text { - All dogs that survived the postoperative period were alive at } \\
\text { follow-up ( } 18 / 23 \text { that had surgery), and owners described } \\
\text { the clinical outcome after surgery as excellent (complete } \\
\text { resolution of clinical signs). Mean follow-up time was } 13.9 \\
\text { months with a range of } 1.0-34.0 \text { months } \\
\text { Cholecystectomy for dogs with GBM is associated with } \\
\text { substantial perioperative mortality rate of } 21.7 \%(5 / 23)\end{array}$ \\
\hline Limitations: & $\begin{array}{l}\text { - This is a retrospective study, and therefore has more bias } \\
\text { than a prospective study } \\
\text { - Patients were included in the study if they had } \\
\text { ultrasonographic evidence of GBM, but it is unknown if } \\
\text { these records were reviewed in a consistent manner before } \\
\text { patient inclusion } \\
\text { - Follow-up information was only collected for patients that } \\
\text { underwent cholecystectomy, which is applicable to the } \\
\text { purpose of this study but does not evaluate long-term } \\
\text { survival outcomes for patients that either underwent } \\
\text { medical management or those that did not receive surgical } \\
\text { treatment } \\
\text { Mean follow-up period was } 13.9 \text { months (range 1-34 } \\
\text { months), and was only collected from a total of six dogs, } \\
\text { although researchers attempted to reach all surviving } \\
\text { patients' owners; survival analysis was performed } \\
\text { Does not discuss or separate cases of uncomplicated GBM } \\
\text { from complicated cases (gallbladder rupture, peritonitis, } \\
\text { extrahepatic biliary tract rupture) } \\
\text { Outcome of the patient's clinical signs was owner reported, } \\
\text { although there was some standardization in how they were } \\
\text { classified as either excellent, fair, or poor based on } \\
\text { researcher definition }\end{array}$ \\
\hline
\end{tabular}

\section{Appraisal, application and reflection}

Traditionally, GBM cases are presented on an emergent basis due to gallbladder rupture or other complications (peritonitis, extrahepatic biliary tract rupture, etc.), but more cases are presenting with incidental ultrasonographic findings of uncomplicated GBM (Smalle et al. 2015). Usually these emergent cases are treated surgically with a cholecystectomy, but little is known about treatment recommendations for incidental and uncomplicated cases. 
Parkanzky et al. (2019) showed a significantly longer difference in long-term survival for surgically managed cases over those medically managed cases of canine GBM, but this was a retrospective analysis of medical records and did not separate uncomplicated cases from complicated cases. The method of medical management was also not standardised between patients. There were also more patients lost to follow-up in the medically managed group than the surgically managed group, which may lead to bias in the analysis of long-term survival. The retrospective nature of this study also creates implicit bias due to differences in diagnostic approach, recommended treatments, and case follow-up that may vary between case and attending clinician.

Other studies included in this Knowledge Summary did not primarily aim to compare MST between the two treatment types, but did provide some survival data. Allerton et al. (2018) reported survival in Border Terrier and non-Border Terrier cases with GBM. There was data provided at 7 days, 6 months, and 1 year survival between medically and surgically managed cases, but with no significant difference between the groups at any of the follow-up periods. There were significantly more dogs in the surgically managed group than the medically managed group ( 77 and 12 respectively). However, the aim of this study was to determine if there was a breed disposition for GBM in Border Terriers, and comparison of medical and surgical management was not the primary outcome measure. Pike et al. (2004) does not provide long-term survival analysis, but does provide some survival data in which all of the patients that survived 14 days post-surgery were still alive after an average follow-up of 13.9 months (range 1.0-34.0 months). This data was only provided on six of the patients in total, further limiting conclusions that can be drawn from the study as it relates to the PICO question.

The application of the included studies is still debatable. There are currently no prospective studies comparing medical and surgical management of uncomplicated GBM in dogs. In order to more accurately recommend which type of treatment will offer better long-term survival in uncomplicated cases of gallbladder mucoceles, a prospective study comparing MST between surgically and medically managed cases would be ideal, but would likely not obtain ethical approval.

\section{Methodology Section}

\begin{tabular}{|c|c|}
\hline \multicolumn{2}{|l|}{ Search Strategy } \\
\hline $\begin{array}{r}\text { Databases searched and dates } \\
\text { covered: }\end{array}$ & $\begin{array}{l}\text { CAB Abstracts on OVID Platform; 1991-2021 } \\
\text { PubMed on NCBI Platform; 1920-current }\end{array}$ \\
\hline Search terms: & $\begin{array}{l}\text { CAB Abstracts: } \\
\text { 1. } \\
\text { 2. ((gallbladder and (mucocele or mucocoele)) or (biliary and } \\
\text { (mucocele or mucocoele))).mp. } \\
\text { 3. cholecystectom*.mp. } \\
\text { 4. (cholecystectom* or medical).mp. } \\
\text { 5. } 1 \text { and } 2 \text { and } 4(46) \\
6.1 \text { and } 2 \text { and } 3(34) \\
\text { PubMed: } \\
\text { ((gallbladder mucocele) OR (biliary mucocele)) AND ((dog) OR } \\
\text { (canine)) AND ((cholecystectomy) OR (medical)) }\end{array}$ \\
\hline Dates searches performed: & 09 Apr 2021 \\
\hline
\end{tabular}




\section{Exclusion / Inclusion Criteria}

Exclusion: Not relevant to PICO, articles not available in English, case reports, book chapters or review articles

Inclusion: Articles available in English which were relevant to PICO

\begin{tabular}{|l|c|c|c|c|c|c|c|}
\hline \multicolumn{7}{|l|}{ Search Outcome } \\
\hline Database & $\begin{array}{c}\text { Number } \\
\text { of results }\end{array}$ & $\begin{array}{c}\text { Excluded - } \\
\text { not } \\
\text { relevant to } \\
\text { PICO }\end{array}$ & $\begin{array}{c}\text { Excluded - } \\
\text { non- } \\
\text { English } \\
\text { language }\end{array}$ & $\begin{array}{c}\text { Excluded - } \\
\text { review } \\
\text { article }\end{array}$ & $\begin{array}{c}\text { Excluded - } \\
\text { case } \\
\text { reports }\end{array}$ & $\begin{array}{c}\text { Excluded - } \\
\text { book } \\
\text { chapter }\end{array}$ & $\begin{array}{c}\text { Total } \\
\text { relevant } \\
\text { papers }\end{array}$ \\
\hline $\begin{array}{l}\text { CAB } \\
\text { Abstracts }\end{array}$ & 51 & 33 & 9 & 1 & 6 & 1 & 1 \\
\hline PubMed & 46 & 40 & 0 & 1 & 2 & 0 & 3 \\
\hline \multicolumn{2}{|l|}{ Total relevant papers when duplicates removed } & & & 3 \\
\hline
\end{tabular}

\section{CONFLICT OF INTEREST}

The authors declare no conflict of interest.

\section{REFERENCES}

1. Allerton, F., Swinbourne, F., Barker, L., Black, V., Kathrani, A., Tivers, M., Henriques, T., Kisielewicz, C., Dunning, M. \& Kent, A. (2018). Gall bladder mucoceles in Border terriers. Journal of Veterinary Internal Medicine. 32(5), 1618-1628. DOI: https://doi.org/10.1111/ivim.15249

2. Parkanzky, M., Grimes, J., Schmiedt, C., Secrest, S. \& Bugbee, A. (2019). Long-term survival of dogs treated for gallbladder mucocele by cholecystectomy, medical management, or both. Journal of Veterinary Internal Medicine. 33(5), 2057-2066. DOI: https://doi.org/10.1111/jvim.15611

3. Pike, F.S., Berg, J., King, N.W., Penninck, D.G. \& Webster, C.R.L. (2004). Gallbladder mucocele in dogs: 30 cases (2000-2002). Journal of American Veterinary Medical Association. 224(10), 1615-1622. DOI: https://doi.org/10.2460/javma.2004.224.1615

4. Smalle, T.M., Cahalane, A.K. \& Köster, L.S. (2015). Gallbladder mucocoele: A review. Journal of the South African Veterinary Association. 86(1), 1318. DOI: https://doi.org/10.4102/isava.v86i1.1318 


\section{EVIIDEFeE

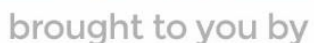 \\ RCVS KNOWLEDGE}

\section{Intellectual Property Rights}

Authors of Knowledge Summaries submitted to RCVS Knowledge for publication will retain copyright in their work, and will be required to grant RCVS Knowledge a non-exclusive license of the rights of copyright in the materials including but not limited to the right to publish, re-

publish, transmit, sell, distribute and otherwise use the materials in all languages and all media throughout the world, and to license or permit others to do so.

\section{Disclaimer}

Knowledge Summaries are a peer-reviewed article type which aims to answer a clinical question based on the best available current evidence. It does not override the responsibility

of the practitioner. Informed decisions should be made by considering such factors as individual clinical expertise and judgement along with patient's circumstances and owners' values. Knowledge Summaries are a resource to help inform and any opinions expressed within the Knowledge Summaries are the author's own and do not necessarily reflect the view of the RCVS Knowledge. Authors are responsible for the accuracy of the content. While the

Editor and Publisher believe that all content herein are in accord with current recommendations and practice at the time of publication, they accept no legal responsibility

for any errors or omissions, and make no warranty, express or implied, with respect to material contained within.

For further information please refer to our Terms of Use.

RCVS Knowledge is the independent charity associated with the Royal College of Veterinary Surgeons (RCVS). Our ambition is to become a global intermediary for evidence based veterinary knowledge by providing access to information

that is of immediate value to practicing veterinary professionals and directly contributes to evidence based clinical decision-making.

https://www.veterinaryevidence.org/

RCVS Knowledge is a registered Charity No. 230886.

Registered as a Company limited by guarantee in England and Wales No. 598443.

Registered Office: Belgravia House, 62-64 Horseferry Road, London SW1P 2AF

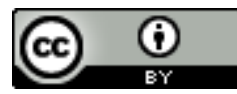

This work is licensed under a Creative Commons Attribution 4.0 International License 